\title{
Characterization of Vietnamese Lacquer Collected in Different Seasons
}

\author{
Rong Lu, ${ }^{1}$ Kenichiro Anzai, ${ }^{1}$ Bach Trong Phuc, ${ }^{2}$ and Tetsuo Miyakoshi ${ }^{1}$ \\ ${ }^{1}$ Department of Applied Chemistry, School of Science and Technology, Meiji University, 1-1-1 Higashi-mita, Tama-ku, \\ Kawasaki-shi 214-8571, Japan \\ ${ }^{2}$ Research Center for Polymer Materials, Hanoi University of Science and Technology, Hai Ba Trung District, Hanoi, Vietnam \\ Correspondence should be addressed to Rong Lu; lurong@meiji.ac.jp
}

Received 20 January 2015; Revised 12 March 2015; Accepted 12 March 2015

Academic Editor: S. M. Sapuan

Copyright (C) 2015 Rong Lu et al. This is an open access article distributed under the Creative Commons Attribution License, which permits unrestricted use, distribution, and reproduction in any medium, provided the original work is properly cited.

Vietnamese lacquers collected every month from June to March of next year were characterized. Composition analysis showed that lacquer collected in rainy season contained much water, while those collected in dry season contained more lipid component. Although hardness of lacquer films is not very hard, lacquers tapped in all seasons can reach hard dry (HD) within 48 hours. Refining lacquer can accelerate drying time but the water concentration should be maintained around $10 \mathrm{wt} \%$ for laccase activity.

\section{Introduction}

Lacquer is sap collected from lacquer tree, which belongs to Anacardiaceae and Toxicodendron families growing in Asia. It has been used as coating material for thousands of years in Asian countries due to durability and beauty [1-4]. Lacquer from Toxicodendron vernicifluum lacquer tree, which grows in China, Japan, and Korea, is usually collected from June to October, and the characters are somewhat different according to the collection month [5]. For example, lacquer tapped from June to July (rainy season in East Asia) contains much water and dries faster than another season. Lacquer tapped in August has better gloss and transparency due to the higher lipid component compared with other seasons. These characters of lacquer depend on the climate during the collection season. Therefore, in lacquer market, the price differs according to collection season and lacquer collected in August with high lipid content fetches the highest price.

In South Asia, especially in Vietnam, lacquer is collected from Toxicodendron succedaneum lacquer trees from January to December because of tropical climate [6]. Vietnamese people have used T. succedaneum lacquer sap as adhesive and coating material in their long lacquer culture history [7-11]. Composition and characterization of laccol [12] and synthesis of epoxy resin derivative from laccol [13] also have been reported. However, how to improve the quality of Vietnamese lacquer is rarely reported.
In the lacquer market, Vietnamese lacquer has relatively poor reputation because of its slow drying and soft film. It has been said that Vietnamese lacquer collected throughout the year is combined in one barrel. This practice may be one reason it has a reputation for low quality in international lacquer market. In order to better understand the real quality and characteristics of Vietnamese lacquer, Vietnamese lacquer saps collected every month from June of 2012 to March of 2013 were analyzed. The composition, drying time, laccase activity, and infrared absorption of lacquer film collected during those months were determined; the characteristics of Vietnamese lacquer are discussed. In addition, development of fast drying lacquer was also carried out by refining (kurome) process, and the results are also discussed.

\section{Experimental}

2.1. Materials. Lacquer sap was tapped from Toxicodendron succedanea lacquer tree growing in Tho Van (T6-T3 series) and Di Nau (D6-D3 series) communes of Tam Nong, Pho Tho, Vietnam, every month from June 2012 to March 2013. Because the quantity collected was inadequate for use in the kurome study, lacquer sap collected in September 2012 in Tho Van commune which was provided by United Nations Industrial Development Organization (UNIDO) of Vietnam was used in the kurome process. 
2.2. Method. Lacquer viscosity was determined at room temperature using a Brookfield Engineering Laboratories programmable DV-II viscometer with a CPE-51 spindle. The rotation speed was $5-20 \mathrm{rpm}$, and the measurement volume was $0.5 \mathrm{~mL}$.

Drying time was carried out using an automatic drying time recorder (Tai Yu Equipment, Osaka, Japan), and the thickness of the tested lacquer films on the glass plate was $76 \mu \mathrm{m}$ when wet as we previously reported [14].

The hardness and color change of lacquer film were measured by pencil hardness tester (Yoshimituseiki, Japan) and Color-Guide instrument (BYK-Gardner, Germany), respectively. ATR-IR spectra of lacquer films were measured using JASCO FT-IR410 spectrophotometer.

Laccase activity was determined using $0.216 \mathrm{mmol} / \mathrm{L}$ syringaldazine/methanol as substrate in $0.1 \mathrm{mmol} / \mathrm{L}$ sodium phosphate buffer ( $\mathrm{pH}$ 6.5) and measured by monitoring the increase in UV absorbance at $525 \mathrm{~nm}$ at $30^{\circ} \mathrm{C}$. One unit of enzyme was equal to an increase of 0.001 absorbance unit per min per mg of acetone powder (AP).

The kurome process is microdispersal of water molecules and dehydration of lacquer sap by mixing. In this study, the kurome process was carried out by changing rotating speed and mixing time, as described in our previous report [15].

Molecular weight distribution and average molecular weight were determined at $40^{\circ} \mathrm{C}$ by gel permeation chromatography (GPC, TSK-gel columns $\alpha-3000, \alpha-4000$, and $\alpha$-M, $\varphi 7.8 \mathrm{~mm} \times 300 \mathrm{~mm} \times 3$, Tosoh). Dimethylformamide (DMF) with $0.01 \mathrm{~mol}$ of $\mathrm{LiBr}$ was used as an eluent on a high-performance liquid chromatography system (HPLC). A refractive-index detector was used and polystyrene having molecular weights of $1.90 \times 10^{5}, 4.39 \times 10^{4}, 5.40 \times 10^{3}$, and 5.00 $\times 10^{2} \mathrm{~g} / \mathrm{mol}$ was used as standards. The elution rate and pressure of the DMF eluent were $0.8 \mathrm{~mL} / \mathrm{min}$ and $48 \mathrm{~kg} / \mathrm{cm}^{2}$, respectively.

\section{Result and Discussion}

3.1. Composition Analysis of Season Lacquers. After measuring the viscosities, lacquer samples were separated with acetone to obtain lipid component and acetone powder (AP). The separation results and viscosities are summarized in Table 1.

The lacquers collected from June to September (T6T9, D6-D9) had higher water concentration compared with those collected from October to January (T10-T1, D10-D1). May to October is rainy and November to March is dry season in Vietnam. Obviously, the water concentration in lacquer is related to climate, and this phenomenon affected lacquer collected from Toxicodendron vernicifluum lacquer tree growing in China, Japan, and Korea. Although February and March are not a rainy season, lacquer collected in both months had a high water concentration, which can be considered due to high humidity in this season in Vietnam. However, we found that the ratio of AP increased with increasing concentration of water, and the water concentration to AP ratio was constant as shown in Figure 1. This phenomenon means that the higher water concentration in lacquer sap is not simply matter of rain or humidity when collected in rainy season or the very
TABLE 1: Compositions of season Vietnamese lacquer.

\begin{tabular}{lcccccc}
\hline Samples & Area & Month & $\begin{array}{c}\text { Lipid } \\
(\%)\end{array}$ & AP (\%) & $\begin{array}{c}\text { Water } \\
(\%)\end{array}$ & $\begin{array}{c}\text { Viscosity } \\
(\mathrm{mPas})\end{array}$ \\
\hline T6 & & 6 & 43.22 & 21.38 & 35.39 & 4447 \\
T7 & & 7 & 43.85 & 21.23 & 34.92 & 3113 \\
T8 & & 8 & 62.40 & 14.17 & 23.43 & 549 \\
T9 & & 9 & 55.56 & 15.74 & 28.70 & 1088 \\
T10 & Tho & 10 & 61.32 & 13.11 & 25.57 & 726 \\
T11 & Van & 11 & 62.17 & 13.15 & 24.68 & 778 \\
T12 & & 12 & 59.35 & 13.91 & 26.74 & 713 \\
T1 & & 1 & 62.26 & 13.58 & 24.16 & 818 \\
T2 & & 2 & 29.43 & 24.71 & 45.86 & 8865 \\
T3 & & 3 & 29.84 & 24.22 & 45.94 & 7525 \\
\hline D6 & & 6 & 70.42 & 11.12 & 18.47 & 1012 \\
D7 & & 7 & 39.23 & 23.43 & 37.34 & 3659 \\
D8 & & 8 & 37.42 & 25.20 & 37.38 & 7387 \\
D9 & & 9 & 46.49 & 20.21 & 33.30 & 1779 \\
D10 & Di & 10 & 61.34 & 13.84 & 24.82 & 811 \\
D11 & Nau & 11 & 66.13 & 13.85 & 20.02 & 713 \\
D12 & & 12 & 38.87 & 24.49 & 36.64 & 2195 \\
D1 & & 1 & 59.03 & 16.87 & 24.10 & 726 \\
D2 & & 2 & 49.73 & 20.30 & 29.97 & 1300 \\
D3 & & 3 & 44.52 & 21.37 & 34.10 & 1884 \\
\hline & & & & & & \\
\hline
\end{tabular}

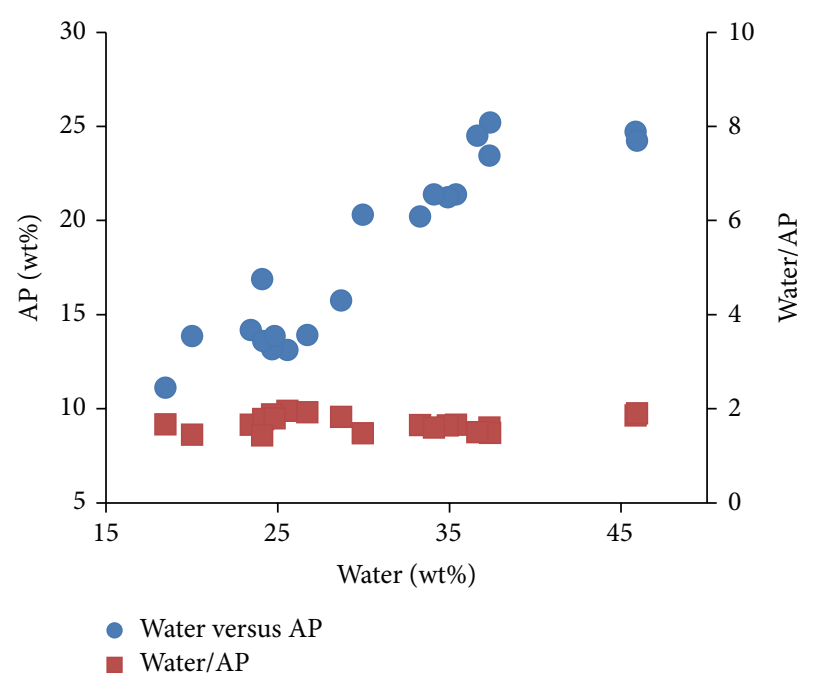

FIgURE 1: Ratio of water to AP.

humid months of February and March. A lacquer tree is a higher plant, its life activity is very complex, and there is much that we humans do not understand. It can also be seen that seasonal lacquer viscosities increased with increasing water concentration, as shown in Figure 2. That is, the energy of emulsification is increased with increasing percentage of water in lipid.

The drying time and hardness of lacquer films are summarized in Table 2. The drying time does not differ much by collecting season, because the drying time is related to 
TABle 2: Compositions of season Vietnamese lacquer.

\begin{tabular}{|c|c|c|c|c|c|c|c|c|c|c|c|c|}
\hline \multirow{2}{*}{ Samples } & \multicolumn{3}{|c|}{ Drying time $^{1}(\mathrm{~h})$} & \multicolumn{9}{|c|}{ Hardness $^{2}$ for drying days } \\
\hline & DF & $\mathrm{TF}$ & $\mathrm{HD}$ & 1 & 2 & 3 & 4 & 5 & 6 & 7 & 14 & 21 \\
\hline T6 & 4.3 & 5.4 & 8.0 & $<6 \mathrm{~B}$ & $<6 \mathrm{~B}$ & $<6 \mathrm{~B}$ & $<6 \mathrm{~B}$ & $<6 \mathrm{~B}$ & $<6 \mathrm{~B}$ & $<6 \mathrm{~B}$ & $<6 \mathrm{~B}$ & $4 \mathrm{~B}$ \\
\hline T7 & 3.8 & 4.8 & 8.8 & $<6 \mathrm{~B}$ & $<6 \mathrm{~B}$ & $<6 \mathrm{~B}$ & $<6 \mathrm{~B}$ & $<6 \mathrm{~B}$ & $<6 \mathrm{~B}$ & $<6 \mathrm{~B}$ & $<6 \mathrm{~B}$ & $5 \mathrm{~B}$ \\
\hline T8 & 2.6 & 3.2 & 6.0 & $<6 \mathrm{~B}$ & $<6 \mathrm{~B}$ & $<6 \mathrm{~B}$ & $<6 \mathrm{~B}$ & $<6 \mathrm{~B}$ & $<6 \mathrm{~B}$ & $<6 \mathrm{~B}$ & $<6 \mathrm{~B}$ & $4 \mathrm{~B}$ \\
\hline T9 & 6.5 & 7.5 & 15.0 & $<6 \mathrm{~B}$ & $<6 \mathrm{~B}$ & $<6 \mathrm{~B}$ & $<6 \mathrm{~B}$ & $<6 \mathrm{~B}$ & $<6 \mathrm{~B}$ & $<6 \mathrm{~B}$ & $5 \mathrm{~B}$ & $5 \mathrm{~B}$ \\
\hline $\mathrm{T} 10$ & 2.8 & 3.5 & 6.5 & $<6 \mathrm{~B}$ & $<6 \mathrm{~B}$ & $5 \mathrm{~B}$ & $5 \mathrm{~B}$ & $5 \mathrm{~B}$ & $5 \mathrm{~B}$ & $5 \mathrm{~B}$ & $3 \mathrm{~B}$ & $3 \mathrm{~B}$ \\
\hline T11 & 4.0 & 5.0 & 8.5 & $<6 \mathrm{~B}$ & $<6 \mathrm{~B}$ & $<6 \mathrm{~B}$ & $6 B$ & $5 B$ & $5 \mathrm{~B}$ & $5 \mathrm{~B}$ & $3 B$ & $3 B$ \\
\hline $\mathrm{T} 12$ & 4.0 & 4.7 & 8.5 & $<6 \mathrm{~B}$ & $<6 \mathrm{~B}$ & $<6 \mathrm{~B}$ & $6 \mathrm{~B}$ & $5 B$ & $5 B$ & $5 B$ & $3 B$ & $3 B$ \\
\hline $\mathrm{T} 1$ & 7.8 & 8.5 & 16.0 & $<6 \mathrm{~B}$ & $<6 \mathrm{~B}$ & $<6 \mathrm{~B}$ & $<6 \mathrm{~B}$ & $<6 \mathrm{~B}$ & $<6 \mathrm{~B}$ & $<6 \mathrm{~B}$ & $4 \mathrm{~B}$ & $4 \mathrm{~B}$ \\
\hline $\mathrm{T} 2$ & 2.8 & 3.5 & 6.0 & $<6 \mathrm{~B}$ & $<6 \mathrm{~B}$ & $<6 \mathrm{~B}$ & $<6 \mathrm{~B}$ & $<6 \mathrm{~B}$ & $<6 \mathrm{~B}$ & $4 \mathrm{~B}$ & $4 \mathrm{~B}$ & $4 \mathrm{~B}$ \\
\hline T3 & 2.0 & 3.0 & 4.5 & $<6 \mathrm{~B}$ & $<6 \mathrm{~B}$ & $<6 \mathrm{~B}$ & $<6 \mathrm{~B}$ & $<6 \mathrm{~B}$ & $<6 \mathrm{~B}$ & $4 \mathrm{~B}$ & $4 \mathrm{~B}$ & $3 \mathrm{~B}$ \\
\hline D6 & 14.0 & 15.5 & $<48$ & - & $<6 \mathrm{~B}$ & $<6 \mathrm{~B}$ & $<6 \mathrm{~B}$ & $<6 \mathrm{~B}$ & $<6 \mathrm{~B}$ & $<6 \mathrm{~B}$ & $<6 \mathrm{~B}$ & $<6 \mathrm{~B}$ \\
\hline D7 & 6.0 & 8.2 & $<48$ & - & $<6 \mathrm{~B}$ & $<6 \mathrm{~B}$ & $<6 \mathrm{~B}$ & $<6 \mathrm{~B}$ & $<6 \mathrm{~B}$ & $<6 \mathrm{~B}$ & $<6 \mathrm{~B}$ & $4 \mathrm{~B}$ \\
\hline D8 & 3.8 & 5.5 & $<48$ & - & $<6 \mathrm{~B}$ & $<6 \mathrm{~B}$ & $<6 \mathrm{~B}$ & $<6 \mathrm{~B}$ & $<6 \mathrm{~B}$ & $<6 \mathrm{~B}$ & $<6 \mathrm{~B}$ & $<6 \mathrm{~B}$ \\
\hline D9 & 2.7 & 3.2 & 4.5 & $<6 \mathrm{~B}$ & $<6 \mathrm{~B}$ & $6 \mathrm{~B}$ & $5 \mathrm{~B}$ & $5 \mathrm{~B}$ & $5 \mathrm{~B}$ & $5 \mathrm{~B}$ & $3 B$ & $3 \mathrm{~B}$ \\
\hline D10 & 2.5 & 3.0 & 5.0 & $<6 \mathrm{~B}$ & $<6 \mathrm{~B}$ & $<6 \mathrm{~B}$ & $5 B$ & $5 B$ & $5 B$ & $5 B$ & $4 \mathrm{~B}$ & $4 B$ \\
\hline D11 & 6.7 & 7.0 & 15.0 & $<6 \mathrm{~B}$ & $<6 \mathrm{~B}$ & $<6 \mathrm{~B}$ & $5 B$ & $5 B$ & $5 \mathrm{~B}$ & $5 \mathrm{~B}$ & $4 \mathrm{~B}$ & $4 \mathrm{~B}$ \\
\hline D12 & 3.0 & 4.0 & 5.5 & $<6 \mathrm{~B}$ & $<6 \mathrm{~B}$ & $<6 \mathrm{~B}$ & $<6 \mathrm{~B}$ & $<6 \mathrm{~B}$ & $<6 \mathrm{~B}$ & $<6 \mathrm{~B}$ & $4 \mathrm{~B}$ & $4 \mathrm{~B}$ \\
\hline D1 & 3.8 & 4.3 & 8.0 & $<6 \mathrm{~B}$ & $<6 \mathrm{~B}$ & $<6 \mathrm{~B}$ & $<6 \mathrm{~B}$ & $<6 \mathrm{~B}$ & $<6 \mathrm{~B}$ & $<6 \mathrm{~B}$ & $4 \mathrm{~B}$ & $4 \mathrm{~B}$ \\
\hline D2 & 1.5 & 2.0 & 3.5 & $<6 \mathrm{~B}$ & $<6 \mathrm{~B}$ & $<6 \mathrm{~B}$ & $<6 \mathrm{~B}$ & $<6 \mathrm{~B}$ & $<6 \mathrm{~B}$ & $<6 \mathrm{~B}$ & $4 \mathrm{~B}$ & $3 B$ \\
\hline D3 & 1.5 & 2.0 & 3.0 & $<6 \mathrm{~B}$ & $<6 \mathrm{~B}$ & $<6 \mathrm{~B}$ & $<6 \mathrm{~B}$ & $<6 \mathrm{~B}$ & $<6 \mathrm{~B}$ & $4 \mathrm{~B}$ & $4 \mathrm{~B}$ & $3 B$ \\
\hline
\end{tabular}

${ }^{1}$ Drying condition: $25^{\circ} \mathrm{C}, 80 \% \mathrm{RH}$, and wet thickness $76 \mu \mathrm{m}$. DF: dust-free dry; TF: touch-free dry; HD: hard dry.

${ }^{2}$ Based on pencil hardness test method.

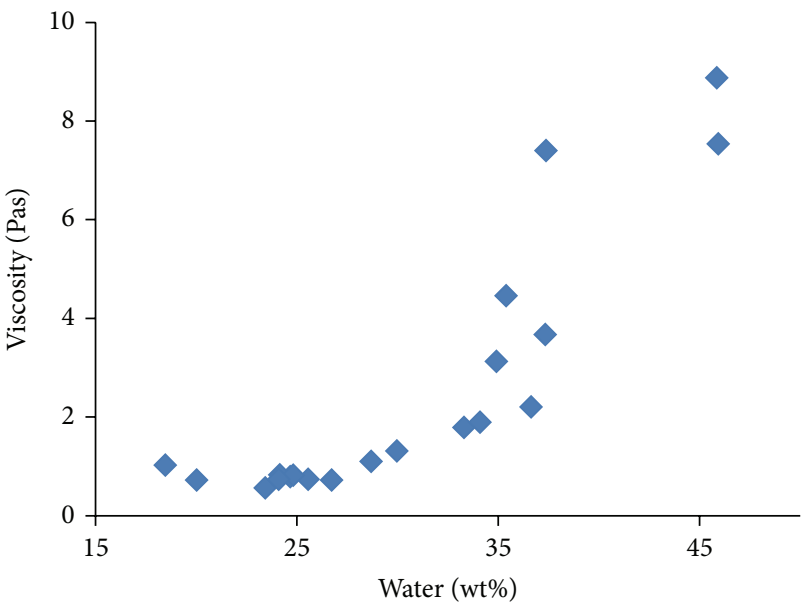

FIGURE 2: Viscosity of lacquer sap.

laccase concentration and activity, and almost all collecting season samples have similar laccase concentration and activity (Table 3). On the other hand, the film hardness is relative to the percentage of lipids in the lacquer sap. Hardness is strongly influenced by the lipid concentration because autoxidation of lipid side chain causes film hardness.

The laccase activity contained in AP was measured using syringaldazine as substrate, and the results are summarized in Table 3. Like drying time, no significant difference was found in the laccase activity by collecting season, and this results in almost the same drying time (Table 2).
TABLE 3: Lacquer laccase activities.

\begin{tabular}{lccc}
\hline Samples & $\begin{array}{c}\text { Activities } \\
\text { (unit/mg AP) }\end{array}$ & Samples & $\begin{array}{c}\text { Activities } \\
\text { (unit/mg AP) }\end{array}$ \\
\hline T6 & 555 & D6 & 693 \\
T7 & 556 & D7 & 416 \\
T8 & 750 & D8 & 538 \\
T9 & 552 & D9 & 455 \\
T10 & 669 & D10 & 710 \\
T11 & 645 & D11 & 528 \\
T12 & 697 & D12 & 329 \\
T1 & 614 & D1 & 746 \\
T2 & 570 & D2 & 534 \\
T3 & 617 & D3 & 447 \\
\hline
\end{tabular}

TABLE 4: Composition percentage, lipid/AP, and contact angle of lacquer films.

\begin{tabular}{lccccc}
\hline Samples & \multicolumn{5}{c}{$\begin{array}{c}\text { Composition percentage } \\
\text { (wt\%) }\end{array}$} \\
& Lipid & AP & Water & Lipid/AP & $\begin{array}{c}\text { Contact angle } \\
\text { (degree) }\end{array}$ \\
\hline T3 & 29.8 & 24.2 & 45.9 & 1.23 & 67.0 \\
T7 & 43.8 & 21.2 & 34.9 & 2.07 & 72.5 \\
T11 & 62.2 & 13.2 & 24.7 & 4.73 & 77.0 \\
\hline
\end{tabular}

Because components are rather different depending on the collection season and lacquer dries by evaporation of water, we hypothesized that dry lacquer films have different properties. In order to reveal the reason, we analyzed the contact angle of drying lacquer films, T3, T7, and T11, and the results are summarized in Table 4 . It can be seen that 
TABLE 5: Data results of kneaded lacquers.

\begin{tabular}{lccccccccc}
\hline $\begin{array}{l}\text { Kneading speed } \\
(\mathrm{rpm})\end{array}$ & $\begin{array}{c}\text { Kneading } \\
\text { time (min) }\end{array}$ & $\begin{array}{c}\text { Water } \\
(\%)\end{array}$ & $\begin{array}{c}\text { Viscosities } \\
(\mathrm{mPas})\end{array}$ & Monomer & Oligomer & Polymer & DF & TF & HD \\
\hline- & - & 35.4 & 1203 & 86.8 & 13.0 & 0.2 & 7.8 & 8.1 & 12.5 \\
\hline 60 & 15 & 26.4 & 1400 & 73.8 & 25.6 & 0.6 & 12.2 & 13.8 & 31.5 \\
60 & 30 & 20.4 & 2442 & 56.5 & 41.8 & 1.7 & 6.6 & 7.2 & 11.8 \\
60 & 45 & 13.6 & 2694 & 50.1 & 48.1 & 1.8 & 2.8 & 3.3 & 5.5 \\
60 & 60 & 12.5 & 4639 & 44.8 & 52.8 & 2.4 & 2.2 & 2.7 & 5.2 \\
\hline 120 & 15 & 27.1 & 3192 & 66.9 & 32.6 & 0.5 & 15.8 & 19.0 & 96 \\
120 & 30 & 16.6 & 2747 & 54.1 & 45.0 & 1.0 & 3.8 & 4.5 & 7.5 \\
120 & 45 & 8.1 & 3558 & 51.3 & 45.3 & 1.6 & 3.0 & 3.4 & 4.5 \\
120 & 60 & 5.2 & 3625 & 50.2 & 47.4 & 2.4 & 3.4 & 3.8 & 6.0 \\
\hline 180 & 15 & 21.5 & 1936 & 67.4 & 32.0 & 0.6 & 16.2 & 18.5 & 72 \\
180 & 30 & 9.0 & 2250 & 56.1 & 42.7 & 1.1 & 1.7 & 2.8 & 6.0 \\
180 & 45 & 5.2 & 2389 & 55.7 & 42.7 & 1.6 & 3.3 & 3.6 & 7.0 \\
180 & 60 & 4.3 & 3322 & 52.3 & 45.8 & 1.9 & 3.1 & 3.7 & 6.0 \\
\hline
\end{tabular}

${ }^{1}$ Determined by GPC. Monomer: MW = 320; oligomer: $10000>$ MW > 600; polymer: $\mathrm{MW}>10000$.

${ }^{2}$ Drying condition: $25^{\circ} \mathrm{C}, 80 \% \mathrm{RH}$, and wet thickness $76 \mu \mathrm{m}$. DF: dust-free dry; TF: touch-free dry; HD: hard dry.

TABLE 6: Lightness, gloss, and coloration of kneaded lacquer films ${ }^{1}$.

\begin{tabular}{lccccc}
\hline $\begin{array}{l}\text { Kneading } \\
\text { speed }(\mathrm{rpm})\end{array}$ & $\begin{array}{c}\text { Kneading } \\
\text { time }(\mathrm{min})\end{array}$ & \multicolumn{4}{c}{ Lightness and coloration } \\
\end{tabular}

${ }^{1}$ Drying condition: $25^{\circ} \mathrm{C}, 80 \% \mathrm{RH}$, and wet thickness $76 \mu \mathrm{m}$.

${ }^{2} L^{*}$ : lightness; $a^{*}:$ +red/-green; $b^{*}:$ +yellow/-blue.

the contact angle increased with decreasing percentage of AP. Figure 3 shows ATR-IR spectra of T3, T7, and T11 lacquer films. Increasing stretch vibrations of hydroxyl group (O$\mathrm{H})$ at $3330 \mathrm{~cm}^{-1}$ and ether $(\mathrm{C}-\mathrm{O})$ or alcohol $(\mathrm{C}-\mathrm{OH})$ at $1037 \mathrm{~cm}^{-1}$ were discernible with increasing percentage of AP. The major component of AP is polysaccharide, and polysaccharides dissolve in water micelles that are dispersed in the $\mathrm{W} / \mathrm{O}$ emulsion of lacquer sap to form a film after drying, when the polysaccharide usually appears at the surface of lacquer film. It was suggested that increasing polysaccharides made lacquer film more hydrophilic.

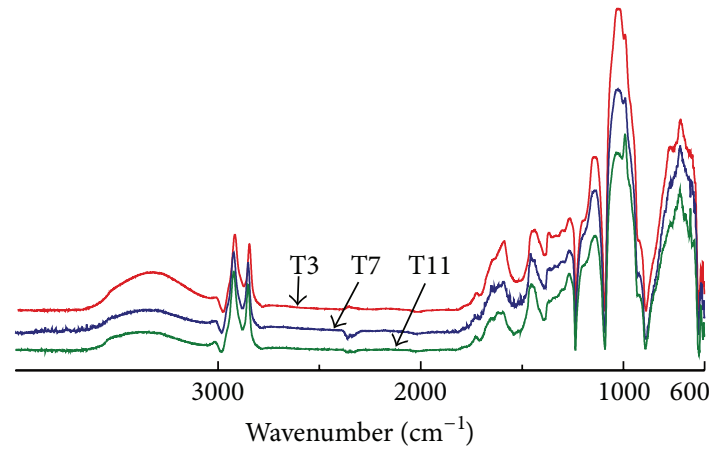

FIgURE 3: ATR-IR spectra of lacquer film.

From the above analyses, it can be concluded that although selecting the best season to collect high quality Vietnamese lacquer sap is difficult, sap collected in dry season (from September to December) has a higher percentage of lipid that gives the film high hardness, and the sap collected in other seasons has a higher percentage of water and AP that makes the film more hydrophilic.

3.2. Development of Fast Drying Lacquer. In order to improve the performance of Vietnamese lacquer, we performed differential kurome process with kneading speed of 60, 120, and $180 \mathrm{rpm}$ and kneading time of 15,30, 45, and $60 \mathrm{~min}$, as summarized in Table 5. During the kurome process, the water concentration decreased with increasing kneading speed, and enzymatic polymerization of the lacquer sap was promoted. The polymerization of lacquer sap is catalyzed by the laccase contained in water micelles and requires oxygen. A high kneading speed beats in more oxygen and promotes polymerization. On the other hand, a high kneading speed also quickly evaporates water, which then decreases laccase 
TABLE 7: Data results of repeated kurome lacquers.

\begin{tabular}{|c|c|c|c|c|c|c|c|c|c|}
\hline \multirow{2}{*}{ Water addition } & \multirow{2}{*}{ Kneading time (min) } & \multirow{2}{*}{ Water (\%) } & \multirow{2}{*}{ Viscosities (Pas) } & \multicolumn{3}{|c|}{ MW distribution $(\%)^{1}$} & \multicolumn{3}{|c|}{ Drying time $^{2}(\mathrm{~h})$} \\
\hline & & & & Monomer & Oligomer & Polymer & DF & $\mathrm{TF}$ & $\mathrm{HD}$ \\
\hline \multirow{5}{*}{ None } & 0 & 33.6 & 1.2 & 86.8 & 13.0 & 0.2 & 7.8 & 8.1 & 12.5 \\
\hline & 60 & 5.2 & 6.6 & 50.2 & 47.5 & 2.3 & 3.0 & 3.6 & 8.3 \\
\hline & 90 & 4.3 & 9.0 & 45.9 & 51.2 & 2.8 & 4.4 & 7.4 & 8.6 \\
\hline & 120 & 4.1 & 10.8 & 45.3 & 51.7 & 3.0 & 4.4 & 5.3 & 8.6 \\
\hline & 180 & 4.4 & 10.6 & 45.0 & 51.6 & 3.3 & & & \\
\hline \multirow{4}{*}{$5 \% / 30 \mathrm{~min}$} & 60 & 7.1 & 6.1 & 49.3 & 48.0 & 2.7 & 2.9 & 3.3 & 8.3 \\
\hline & 90 & 4.5 & 7.8 & 44.6 & 52.4 & 3.1 & 3.4 & 3.8 & 5.3 \\
\hline & 120 & 5.1 & 8.4 & 43.5 & 53.2 & 3.3 & 3.5 & 3.9 & 7.7 \\
\hline & 180 & 3.7 & 12.6 & 39.5 & 56.3 & 4.1 & & & \\
\hline \multirow{4}{*}{$10 \% / 30 \mathrm{~min}$} & 60 & 7.8 & 4.2 & 56.1 & 41.2 & 2.7 & 3.4 & 4.2 & 8.6 \\
\hline & 90 & 5.9 & 6.3 & 47.1 & 49.3 & 3.6 & 3.8 & 4.3 & 8.3 \\
\hline & 120 & 4.1 & 10.9 & 40.6 & 54.6 & 4.7 & 3.3 & 3.6 & 7.5 \\
\hline & 180 & 3.8 & 22.4 & 35.9 & 58.2 & 5.9 & & & \\
\hline \multirow{4}{*}{$20 \% / 30 \mathrm{~min}$} & 60 & 7.3 & 5.8 & 48.2 & 47.5 & 4.2 & 3.2 & 4.5 & 8.3 \\
\hline & 90 & 5.5 & 11.2 & 39.6 & 54.8 & 5.6 & 5.5 & 6.4 & 9.0 \\
\hline & 120 & 9.5 & 23.4 & 33.1 & 58.2 & 8.7 & 2.6 & 3.4 & 6.0 \\
\hline & 150 & 12.3 & 43.5 & 30.5 & 59.4 & 10.1 & & & \\
\hline
\end{tabular}

${ }^{1}$ Determined by GPC. Monomer: $\mathrm{MW}=320$; oligomer: $10000>\mathrm{MW}>600$; polymer: $\mathrm{MW}>10000$.

${ }^{2}$ Drying condition: $25^{\circ} \mathrm{C}, 80 \% \mathrm{RH}$, and wet thickness $76 \mu \mathrm{m}$. DF: dust-free dry; TF: touch-free dry; HD: hard dry.

activity. In our previous work [16, 17], it was found that lacquer sap collected from $T$. vernicifluum lacquer trees can be polymerized to form a film even if the water concentration is just over $3 \mathrm{wt} \%$. However, in this study, we found that the lacquer sap collected from $T$. succedanea lacquer trees was not polymerized when the water concentration was lower than $10 \mathrm{wt} \%$. Because the AP concentration in T. succedanea lacquer sap is higher than that in T. vernicifluum lacquer sap, this difference suggested that $T$. succedanea sap requires more water to dissolve the laccase and become polymerized. In general, viscosity of lacquer sap decreases with increasing water concentration. Therefore, the viscosity of kneaded lacquer increased with progression of polymerization due to decrease of water concentration during the kneading process, and the drying time of kneaded lacquer was also substantially shortened with the progress of polymerization.

Gloss, $L^{*}, a^{*}$, and $b^{*}$ are summarized in Table 6. Gloss reached 100 for lacquer saps kneaded for $15 \mathrm{~min}$ at 120 and $180 \mathrm{rpm}$. Kneading at a speed of $60 \mathrm{rpm}$ which needed $60 \mathrm{~min}$ made gloss reach 100. Because water micelles contained in lacquer sap can be microdispersed by kneading and stirring, the film surface becomes smooth and the gloss increases. Water micelles can be miniaturized quickly when the kneading speed is high. At all kneading speeds, $L^{*}, a^{*}$, and $b^{*}$ all decrease as the kneading time increased suggesting that the lacquer film become transparent and color change from red/yellow to green/blue.

In this study, we found that if the water concentration in Vietnamese lacquer is lower than $10 \mathrm{wt} \%$, which was kneaded at $120 \mathrm{rpm}$ for 45 and $60 \mathrm{~min}$ and $180 \mathrm{rpm}$ for 30, 45, and $60 \mathrm{~min}$ (Table 5), the polymerization of laccol catalyzed by laccase should not occur. In order to prevent a decrease in the water concentration, repeated kurome, which is the addition of water every $30 \mathrm{~min}$ during the kneading, was carried out. The results are summarized in Table 7. Kurome can accelerate laccase polymerization of lacquer because as kneading time increases and is repeated, monomer decreases and oligomer increases, and polymer also slightly increases. This phenomenon is consistent with the results from kurome lacquer sap collected from T. vernicifluum lacquer tree [18].

\section{Conclusions}

Lacquer saps collected from Toxicodendron succedanea lacquer tree growing in Vietnam during the rainy season contained a relatively high concentration of water and during the dry season contained a relatively high concentration of lipid component. The compositions of Vietnamese lacquer are affected by collecting season like the lacquer sap collected from Toxicodendron vernicifluum lacquer tree growing in China, Japan, and Korea. The increasing ratio of AP makes the film hydrophilic, and the increasing ratio of lipids increases the film hardness. After being refined by the kurome process, the lacquer polymerizes faster than in its raw state. The polymerization stopped when the amount of water fell below $10 \mathrm{wt} \%$, but the polymerization can be promoted further by adding water during the kneading process, and this is called the repeat-kurome process.

\section{Conflict of Interests}

The authors declare that there is no conflict of interests regarding the publication of this paper. 


\section{Acknowledgments}

The authors thank United Nations Industrial Development Organization (UNIDO) of Vietnam for Toxicodendron succedanea lacquer sample. This work was supported financially in part by a Grant-in-Aid for Scientific Research on Innovative Areas from the Ministry of Education, Culture, Sports, Science and Technology (MEXT) of Japan and by the cooperative research program of the MEXT-Supported Program for the Strategic Research Foundation at Private Universities.

\section{References}

[1] E. J. Kidder, Japan Before Buddhism, Ancient Peoples and Places, Thames \& Hudson, London, UK, 1959.

[2] J. Hu, "Conservation of water-logged lacquerwares unearthed in China," in Conservation and Restoration of Cultural Property: Conservation of Far Eastern Objects, pp. 89-112, Tokyo National Research Institute of Cultural Property, Tokyo, Japan, 1980.

[3] Y. Kuraku, "Origins of the use of urushi in Japan and its development," in Urushi, N. S. Brommelle and P. Smith, Eds., p. 45, Getty Conservation Institute, Los Angeles, Calif, USA, 1988.

[4] Y. M. Du, "The production and use of Chinese raw urushi and the present state of research," in Urushi, N. S. Brommelle and P. Smith, Eds., p. 194, Getty Conservation Institute, Los Angeles, Calif, USA, 1988.

[5] T. Terada, K. Oda, H. Oyabu, and T. Asami, Lacquer-the Science and Practice, Rikou Publisher, Tokyo, Japan, 1999.

[6] T. Miyakoshi, K. Nagase, and T. Yoshida, Progress of Lacquer Chemistry, IPC, Tokyo, Japan, 1999.

[7] D. van Luyen, T. Vinh Dieu, and N. T. Thin, "Synthesis epoxy resin from Vietnamese lacquer sap," Vietnam Journal of Chemistry, vol. 4, p. 31, 1972.

[8] T. V. Dieu, L. T. Phai, and N. T. Cuc, "Study of curing process of epoxy-laccol collected from Vietnamese lacquer sap," Vietnam Journal of Chemistry, vol. 1, p. 26, 1976.

[9] T. V. Dieu and L. T. Phai, "New composite of epoxy from epoxydian cured by laccol," Vietnam Journal of Chemistry, vol. 1, p. 18, 1980.

[10] T. V. Dieu, L. T. Phai, N. H. Yen, and P. H. Quynh, "The factors influence on curing reaction of oligomer epoxy by laccol," Vietnam Journal of Chemistry, vol. 4, p. 24, 1978.

[11] T. V. Dieu, L. T. Phai, and B. T. Phuc, "About resin adhesive from synthetic rubber with metal based on epoxydian resin ED-6, ED-20 and technical laccol collected from Vietnamese lacquer sap," Vietnam Journal of Chemistry, vol. 4, p. 1, 1994.

[12] T. V. Dieu and L. T. Phai, "New hardeners for epoxy resin based on Vietnam natural phenolic lacs, polyamine and formaldehyde," Vietnam Journal of Chemistry, vol. 2, p. 47, 1979.

[13] D. V. Luyen, T. V. Dieu, H. T. Mui, N. T. Cuc, and N. T. Thin, "Composition and characterization of laccol collected from Vietnamese lacquer sap," Vietnam Journal of Chemistry, vol. 2, p. $45,1972$.

[14] R. Lu, T. Ishimura, K. Tsutida, T. Honda, and T. Miyakoshi, "Development of a fast drying hybrid lacquer in a low-relativehumidity environment based on kurome lacquer sap," Journal of Applied Polymer Science, vol. 98, no. 3, pp. 1055-1061, 2005.

[15] K. Nagase, R. Lu, and T. Miyakoshi, "Studies on the fast drying hybrid urushi in low humidity environment," Chemistry Letters, vol. 33, no. 2, pp. 90-91, 2004.
[16] K. Nagase, Y. Kamiya, T. Kimura, K. Hozumi, and T. Miyakoshi, "The relationship between the change of progress time in the urushi liquid by the enzymic polymerization and the natural drying property occurring under a low humidity environment," Nippon Kagaku Kaishi, vol. 2001, no. 10, pp. 587-593, 2001.

[17] K. Nagase, Y. Kamiya, K. Hodumi, and T. Miyakoshi, "The relationship between the change in urushiol by repetitive 'KUROME' of the urushi liquid and natural drying property occurring in a low humidity environment," Nippon Kagaku Kaishi, vol. 3, pp. 377-384, 2002.

[18] R. Lu, S. Harigaya, T. Ishimura, K. Nagase, and T. Miyakoshi, "Development of a fast drying lacquer based on raw lacquer sap," Progress in Organic Coatings, vol. 51, no. 3, pp. 238-243, 2004. 

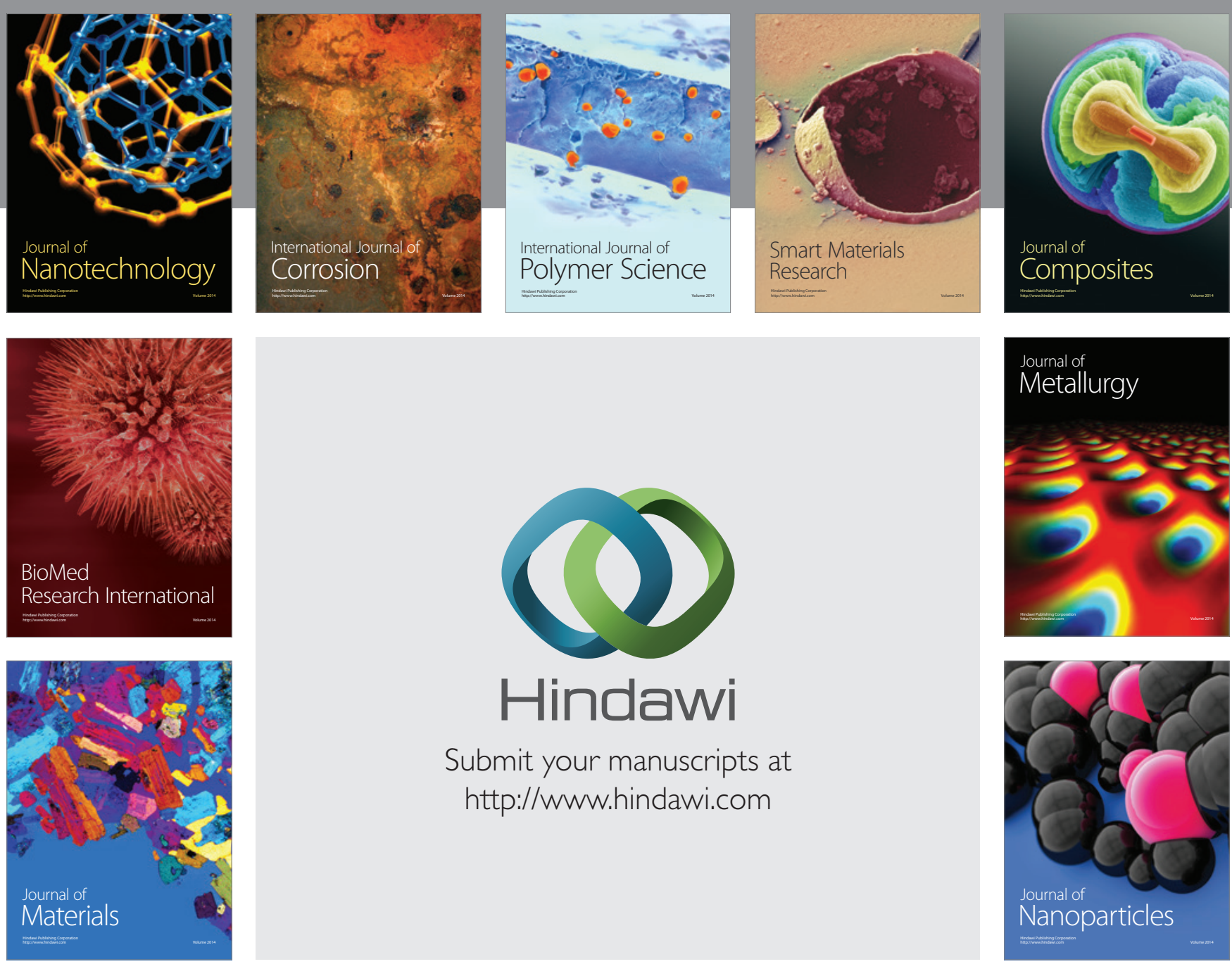

Submit your manuscripts at http://www.hindawi.com
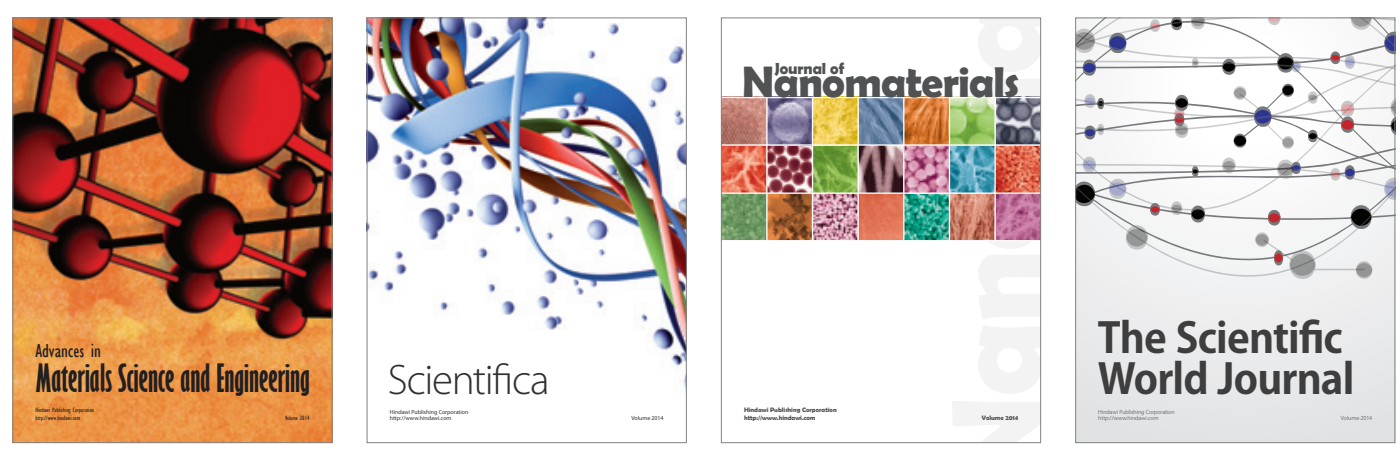

\section{The Scientific World Journal}
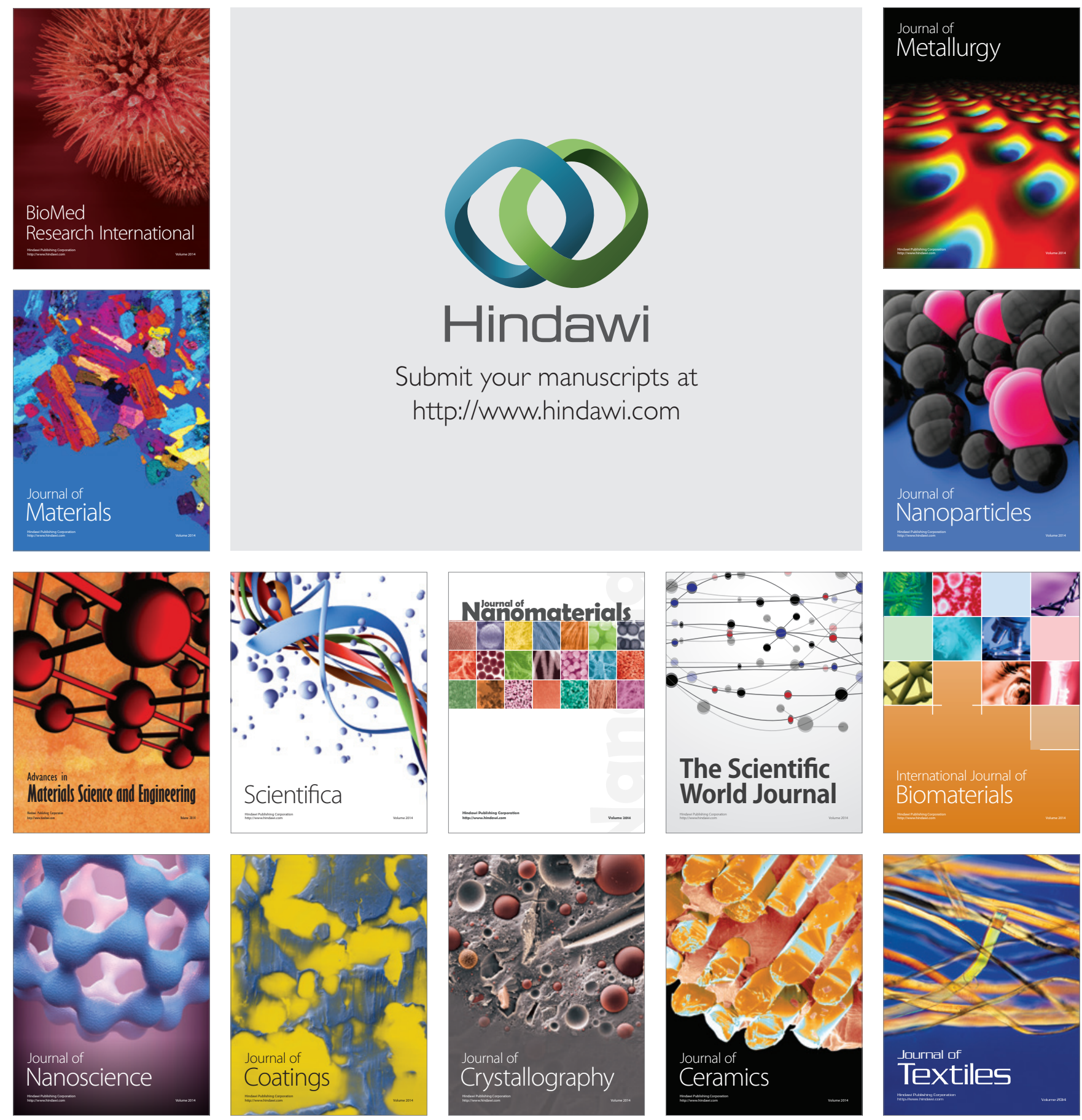